\title{
PREPARATION AND GRAIN-GROWTH OF MAGNESIA-ALUMINA SPINEL/YTTRIUM ALUMINUM GARNET COMPOSITE FIBERS
}

\author{
${ }^{\#}$ XIAOLING MA*,**, ${ }^{\#}$ ZHENLIN LV*, HONGBIN TAN $* *, * * *$, JIAO NAN**, CAIXIA WANG ${ }^{*}, * *$ \\ *School of Materials Science and Engineering, Xi'an University of Technology, \\ $X i$ 'an Shaanxi 710048, People's Republic of China \\ **Shaanxi Engineering Center of Metallurgical Sediment Resource, Shaanxi University of Technology, \\ Hanzhong Shaanxi 723000, People's Republic of China \\ ***School of materials science and Engineering, Southwest University of Science and Technology, \\ Mianyang 621010, People's Republic of China \\ \#E-mail: mxlclx@163.com,lvzl2002@xaut.edu.cn
}

Submitted February 26, 2018; accepted June 15, 2018

\begin{abstract}
Keywords: Magnesia-alumina spinel, Yttrium aluminum garnet, Composite fibers, Grain growth mechanism
Magnesia-alumina spinel/yttrium aluminum garnet composite fibers were prepared by sol-gel method. The spinnability of precursor sol remarkably depended on the addition amount of polyvinylpyrrolidone. Long gel fibers, with $80 \mathrm{~cm}$ in length, were obtained by adding $28 \mathrm{wt}$. \% spinning additive. The phases of composite fibers were magnesia-alumina spinel and yttrium aluminum garnet after heating at $1400^{\circ} \mathrm{C}$ for $2 \mathrm{~h}$. The $\mathrm{Mg}$ iron can hinder the yttrium aluminum garnet grain growth by solute drag and grain boundary pinning. The grain growth exponent was about 3.7 at $1600^{\circ} \mathrm{C}$.
\end{abstract}

\section{INTRODUCTION}

Yttrium aluminum garnet $\left(\mathrm{Al}_{5} \mathrm{Y}_{3} \mathrm{O}_{12}\right.$ or $\left.\mathrm{YAG}\right)$ possesses a cubic structure and constitutes a complex oxide of $\mathrm{Y}_{2} \mathrm{O}_{3}$ and $\mathrm{Al}_{2} \mathrm{O}_{3}$. YAG, with low creep rate, high elastic modulus, high tensile strength, thermal shock resistance, excellent thermal stability, oxidation and reduction atmosphere resistance at high temperatures, has attracted much attention due to its various applications, including high temperature structural materials, host materials for solid-state lasers, transparent armors, window materials $[1,2]$.

In high temperature ceramic materials, YAG demonstrates the best resistance to creep. For example, single crystal YAG exhibits a creep resistance 10 times higher than single crystal alumina [3]. In polycrystalline YAG lattice and boundary diffusion will reduce the creep resistance of the material, but nevertheless, at $1400^{\circ} \mathrm{C}$ polycrystalline YAG is three times better than polycrystalline alumina of the same grain size $(3 \mu \mathrm{m})$ [3]. Although the exact mechanism of creep in single crystal YAG is still uncertain, it is suggested that it is largely a diffusion-controlled process, as the large size of the cubic unit cell and large lattice parameters of the garnet dramatically reduces the number of dislocations, especially climb dislocations which are a key creep mechanism [4].
Ceramic matrix composites (CMC) are leading candidates for high performance structures such as space vehicles, land based turbines, commercial and military aircraft engines, advanced missiles and rockets [5]. YAG fiber is a suitable candidate material which is used as reinforcement in the ceramic matrix, particularly in high temperature applications over $1400^{\circ} \mathrm{C}[4]$.

The creep resistance and strength of polycrystalline ceramics can be improved by the addition of hard second-phase particles and the second-phase particles may affect ceramic grain growth, microstructure, and creep rate by solute drag and grain boundary pinning $[6,7]$. For example, when alumina fibers were prepared by adding $\mathrm{MgO}$ in the fibers, the $\mathrm{MgO}$ reduced the fibers grain size and increased its tensile strength [8].

$\mathrm{MgO}$ was a kind of cheap and common sintering aid to improvement ceramic density for fabricated. Magnesia-alumina spinel $\left(\mathrm{MgAl}_{2} \mathrm{O}_{4}, \mathrm{MAS}\right)$ will be obtained by adding $\mathrm{MgO}$ in alumina. MAS has excellent thermomechanical property, high melting point $\left(2135^{\circ} \mathrm{C}\right)$, good thermal shock resistance, excellent corrosion resistance, low thermal expansion and low dielectric constant [9].

Grain coarsening has a strong negative influence on the mechanical properties of ceramic fibers [10]. Although YAG is one of the most widely studied ceramics, but no comprehensive quantitative research work has been reported on its grain-growth behavior effect of second-phase particles. 
Two main processes for the manufacturing of ceramic fibers existed, including melt-spinning processes and sol-gel spinning processes [11]. Many successful processes have been reported in the preparation of YAG fibers by the sol-gel method $[12,13]$. Conventionally, sol-gel methods are adopted for the ceramic synthesis with high-melting point [13-15].

In the present study, MAS/YAG composite fibers were prepared by the sol-gel method using aluminum chloride, aluminum powder, yttrium oxide, acetic acid and magnesia $(\mathrm{MgO})$ as raw materials. The effect of second-phase particles on YAG grain growth behavior was analyzed using the grain-size data by sintering fibers at $1600^{\circ} \mathrm{C}$ for different time.

\section{EXPERIMENTAL}

\section{Preparation of samples}

The starting materials used were aluminum chloride hexahydrate (chemical grade, Xi'an reagent factory, Xi'an, China), aluminum powder (chemical grade, Shanghai Chemistry Co. Ltd., Shanghai, China), glacial acetic acid (chemical grade, Tianjin Yaohua Chemistry Co. Ltd., Tianjin, China), yttria (99.99 wt. \%, Wanbao Rare-Earth Co. Ltd, Ganzhou, China), magnesia (Chemical grade, Tianjin Kermel Chemistry Co. Ltd., Tianjin, China) and polyvinylpyrrolidone (PVP, chemical grade, Sinopharm Chemical Reagent Co. Ltd, Shanghai, China).

The precursor solution of MAS/YAG was made as before [12], yttria powder, aluminum powder, magnesia and aluminum chloride were dissolved in acetic acid solution when the mixtures were heated and stirred using magnetic stirring under reflux at $80^{\circ} \mathrm{C}$, which the molar ratio of $\mathrm{AlCl}_{3} \cdot 6 \mathrm{H}_{2} \mathrm{O}$ and $\mathrm{Al}$ were $3: 1$, the molar ratio of $\mathrm{Al}$ and $\mathrm{Y}$ were 5:3, the molar ratio of acetic acid and $\mathrm{Y}$ were $1.5: 1$, the molar ratio of $\mathrm{H}_{2} \mathrm{O}$ and $\mathrm{Al}$ were $20: 1$, respectively. According to the mass of raw material, a different amount polyvinylpyrrolidone (PVP) was used as spinning additive. According to the calculated mass of YAG, a 5 wt. \% magnesia $(\mathrm{MgO})$ was added in the solution. Then, the precursor solution was concentrated to obtain spinning sol in water bath $\left(60^{\circ} \mathrm{C}\right)$.

The gel fibers were prepared by pulling a thin glass rod slowly from the sol after immersing. Then the gel fibers were dried at $60^{\circ} \mathrm{C}$ for $24 \mathrm{~h}$ in an oven. The dried gel fibers were then sintered at $1600^{\circ} \mathrm{C}$ for $2,4,6$ and $8 \mathrm{~h}$ with heating rate of $2^{\circ} \mathrm{C} \cdot \mathrm{min}^{-1}$, respectively.

\section{Characterization techniques}

The spinnability was estimated from the maximum length of gel fibers that was drawn from the spinnable condensed sol.

The viscosity measurement of sol was carried out at different temperature by using a rotational viscometer (NDJ-8, Shanghai Fangrui Tech. Co., Ltd., Shanghai, China) at different shear rate $\left(6,12,30\right.$ and $\left.60 \mathrm{r} \cdot \mathrm{min}^{-1}\right)$.
For the gel fibers, thermal behaviors were measured by Thermogravimetry-differential scanning calorimetry (TG/DSC) instruments (SDT Q600, TA Instrument, American) at a heating rate of $10^{\circ} \mathrm{C} \cdot \mathrm{min}^{-1}$ in flowing $\mathrm{N}_{2}$. $\mathrm{X}$-ray diffraction analysis was carried out on an X-ray diffractometer (X'Pert PRO X-ray diffraction, PANalytical, Netherlands) using $\mathrm{CuK} \alpha$ radiation with a step of $0.1 \%$. The morphologies of fibers were characterized by scanning electron microscopy (Stereoscan 440, Leica Cambridge Co., Ltd, U.K.). Grain sizes of the fibers were obtained by the linear intercept method on the surface of fibers and along the axis of fibers or on the cross-section of fibers (at least 50 counts) where the average intercept length was multiplied by 1.5 to calculate the average grain size [16].

\section{RESULTS AND DISCUSSION}

When aluminum chloride hexahydrate $\left(\mathrm{AlCl}_{3} \cdot 6 \mathrm{H}_{2} \mathrm{O}\right)$ was added in water, it was firstly hydrolyzed with water and formed aluminum oxyhydroxides and formed acid solution, chemical reaction can be simplified in the following equation, though the actual reaction is more complex:

$$
\mathrm{AlCl}_{3}+3 \mathrm{H}_{2} \mathrm{O} \rightarrow \mathrm{Al}(\mathrm{OH})_{3}+3 \mathrm{HCl}
$$

Hydrolysis reaction occurred because water molecules coordinated to metal ions were more acidic than in the non-coordinated state due to charge transfer from the oxygen to the metal atom [17]. In the mixed solution of aluminum chloride and acetic acid, yttria and aluminum powder were dissolved during the heating and stirring, and their main chemical reactions can be simplified in the following set of equations:

$$
\begin{gathered}
\mathrm{Y}_{2} \mathrm{O}_{3}+6 \mathrm{HCl} \rightarrow 2 \mathrm{YCl}_{3}+3 \mathrm{H}_{2} \mathrm{O}, \\
\mathrm{Al}+3 \mathrm{HCl} \rightarrow \mathrm{AlCl}_{3}+3 / 2 \mathrm{H}_{2} \uparrow, \\
3 \mathrm{CH}_{3} \mathrm{COOH}+\mathrm{Al} \rightarrow \mathrm{Al}\left(\mathrm{CH}_{3} \mathrm{COO}\right)_{3}+3 / 2 \mathrm{H}_{2} \uparrow \\
6 \mathrm{CH}_{3} \mathrm{COOH}+\mathrm{Y}_{2} \mathrm{O}_{3} \rightarrow 2 \mathrm{Y}\left(\mathrm{CH}_{3} \mathrm{COO}\right)_{3}+3 \mathrm{H}_{2} \mathrm{O}
\end{gathered}
$$

Moreover, yttrium chloride was also hydrolyzed and formed yttrium oxyhydroxides in the acid solution, according to the following chemical reaction:

$$
\mathrm{YCl}_{3}+3 \mathrm{H}_{2} \mathrm{O} \rightarrow \mathrm{Y}(\mathrm{OH})_{3}+3 \mathrm{HCl}
$$

The viscous sol was obtained by condensation because poly-nuclear species are formed by condensation reactions (olation and oxolation) and formation of $\mathrm{M}-\mathrm{OH}-\mathrm{M}$ and $\mathrm{M}-\mathrm{O}-\mathrm{M}$ with linear or non-linear links [17].

Spinnability of the sols with different PVP addition amount is shown in Table 1. The length of gel fiber was remarkably dependent on the PVP addition amount. The maximum length of gel fibers was about $80 \mathrm{~cm}$ when the addition amount of PVP was 28 wt. \%. Al and Y ions 
or particles would coordinate with $\mathrm{N}$ or $\mathrm{O}$ ions in PVP, resulting in the formation of the coordinative complex in aqueous solution. The reactions can be written as (7) and (8), $\mathrm{Al}^{3+}$ as an example [18].

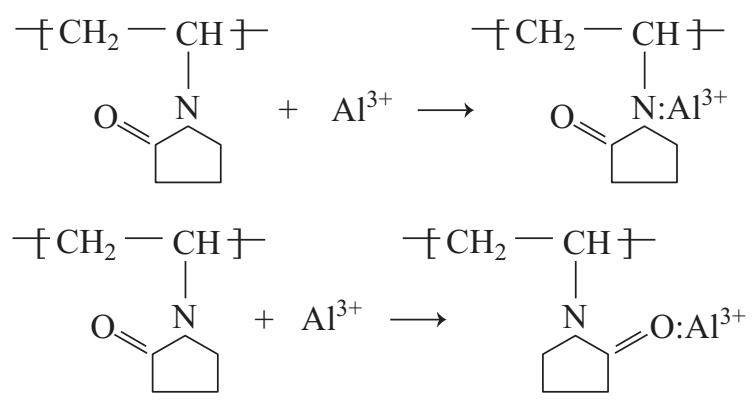

The viscosity of the precursor sol at different temperature is shown in Table 2. The sol has optimal spinnability with 18.5 wt. \% solid content, which solid content was ratio of calculated YAG in sol and sol mass. This was followed by a period of shear thinning behavior (i.e. viscosity decreases as the shear rate increases).

During sol-gel process, intermolecular force between polymers strengthened gradually by the hydrogen bonds or Van der Waals forces. This structure, which can be broken under shear/temperature, resulted in the shear/

Table 1. Spinnability of the sols with different PVP addition amount.

\begin{tabular}{lllll}
\hline PVP addition amount (wt. \%) & 10 & 16 & 22 & 28 \\
\hline Length of gel fibers (cm) & 20 & 30 & 50 & 80 \\
\hline
\end{tabular}

Table 2. Viscosities of the precursor sol at different temperature $(\mathrm{mPa} \cdot \mathrm{s})$.

\begin{tabular}{ccccc}
\hline $\begin{array}{c}\text { Shear rate } \\
\left(\mathrm{r} \cdot \mathrm{min}^{-1}\right)\end{array}$ & 6 & 12 & 30 & 60 \\
\hline $25^{\circ} \mathrm{C}$ & 4291 & 2148 & 858 & 429 \\
$40^{\circ} \mathrm{C}$ & 2452 & 2147 & 859 & 428 \\
$60^{\circ} \mathrm{C}$ & 1719 & 1579 & 858 & 425 \\
\hline
\end{tabular}

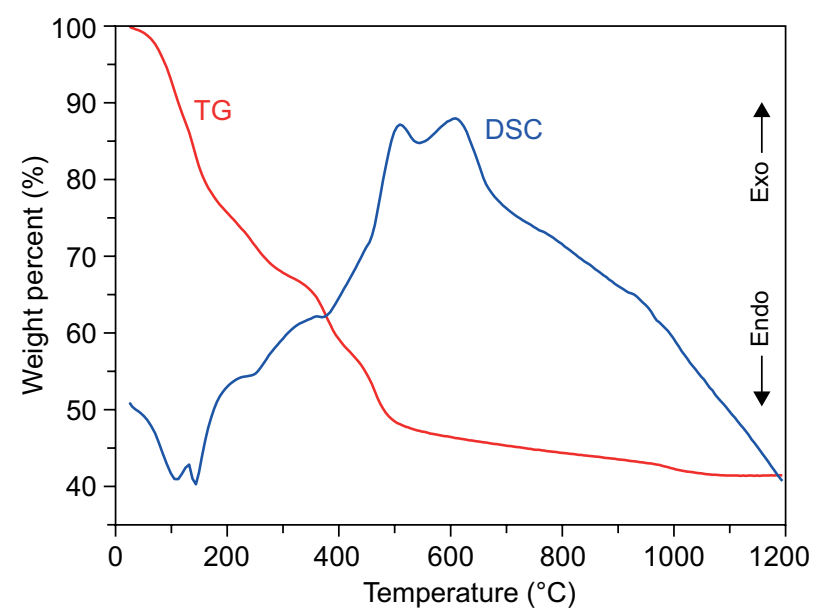

Figure 1. TG/DSC curves of the precursor gel fibers. temperature thinning flow behavior at high viscosity range [10]. At different temperature, the sol had similar viscosity at high shear rate. The viscosity value of sol at $25,40,60^{\circ} \mathrm{C}$, were $429,428,425 \mathrm{mPa}$ s at $60 \mathrm{r} \cdot \mathrm{min}^{-1}$ in shear rate, respectively, which indicated the influence of shear rate was bigger than temperature on sol viscosity.

The TG/DSC curves of the precursor gel fibers are shown in Figure 1 with a heating rate of $10^{\circ} \mathrm{C} \cdot \mathrm{min}^{-1}$. The DSC curve of the gel fibers exhibit three endothermic peaks at about 109,144 , and $545^{\circ} \mathrm{C}$, and two exothermic peaks at about 510 and $608^{\circ} \mathrm{C}$. The endothermic peaks are assigned to dehydration of the residual water, structure water and decomposition of different hydroxides in the gel fibers, whereas the first exothermic peak is assigned to decomposition of organic component, whereas the later exothermic peak is possibly assigned to crystallization of $\mathrm{Al}_{2} \mathrm{Y}_{4} \mathrm{O}_{9}$, respectively. The TG curve of the gel fibers shows the weight loss around 58.6 wt. $\%$ at $1200^{\circ} \mathrm{C}$.

The XRD patterns of the precursor gel fibers sintered at $600,800,1000,1200,1400$ and $1600^{\circ} \mathrm{C}$ for $2 \mathrm{~h}$ are shown in Figure 2. Amorphous phase was observed after the fibers were sintered at $600^{\circ} \mathrm{C}$. The $\mathrm{Al}_{2} \mathrm{Y}_{4} \mathrm{O}_{9}$ and $\mathrm{Y}_{2} \mathrm{O}_{3}$ phases are observed after the fibers were sintered at $800^{\circ} \mathrm{C}$. The $\mathrm{Al}_{2} \mathrm{Y}_{4} \mathrm{O}_{9}$ is main phase after the fibers were sintered at $1000{ }^{\circ} \mathrm{C}$. The $\mathrm{YAlO}_{3}$ is main phase after the fibers were sintered at $1200^{\circ} \mathrm{C}$. The main phases were $\mathrm{Y}_{3} \mathrm{Al}_{5} \mathrm{O}_{12}$ and $\mathrm{MgAl}_{2} \mathrm{O}_{4}$ after the fibers were sintered at 1400 and $1600^{\circ} \mathrm{C}$, respectively.

$\mathrm{Mg}^{2+}$ ion can substitute $\mathrm{Al}^{3+}$ ion in YAG lattice during sintering process $[19,20]$. For a high Mg-dopant level, $\mathrm{Mg}$ ions could be in both a lattice site and an interstitial position in YAG [21]. And some $\mathrm{MgO}$ can react with $\mathrm{Al}_{2} \mathrm{O}_{3}$ to form $\mathrm{MgAl}_{2} \mathrm{O}_{4}$. The $\mathrm{Mg}$ dissolves in YAG solid solution, further research continues to define these dependencies.

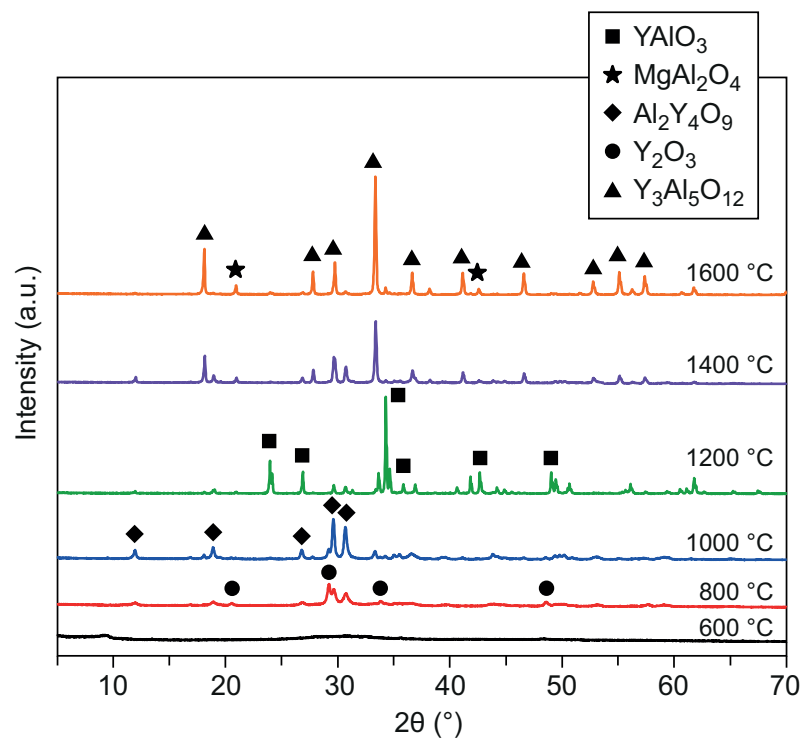

Figure 2. X-ray diffraction patterns of the precursor gel fibers sintered at different temperature for $2 \mathrm{~h}$. 
According to reference $[12,13]$, the YAG crystallizes directly from the amorphous precursor without the formation of any intermediate phase. In this work, the intermediate phase was observed possible because the $\mathrm{MgO}$ hindered YAG crystallizes.

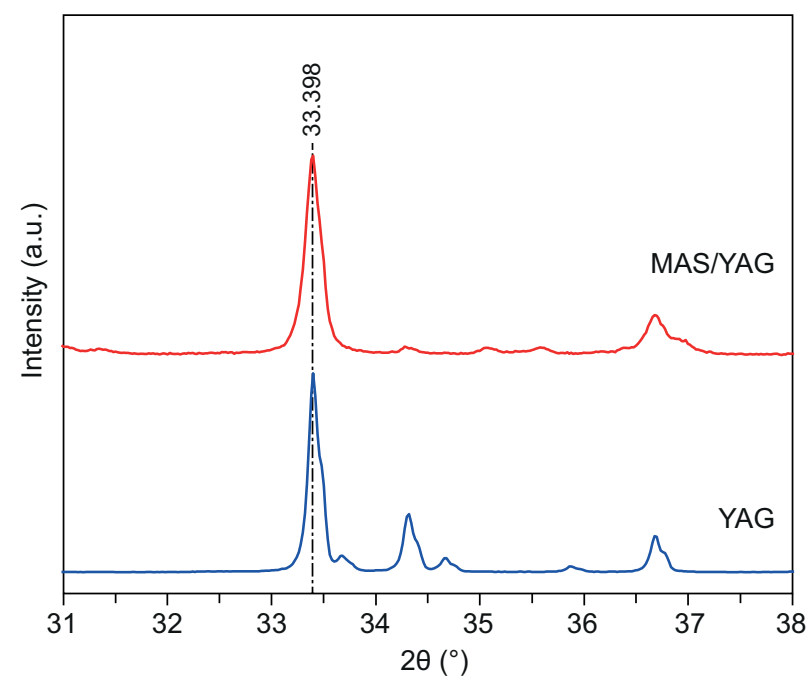

Figure 3. XRD patterns of YAG and the composite fibers sintered at $1600^{\circ} \mathrm{C}$ for $2 \mathrm{~h}$.
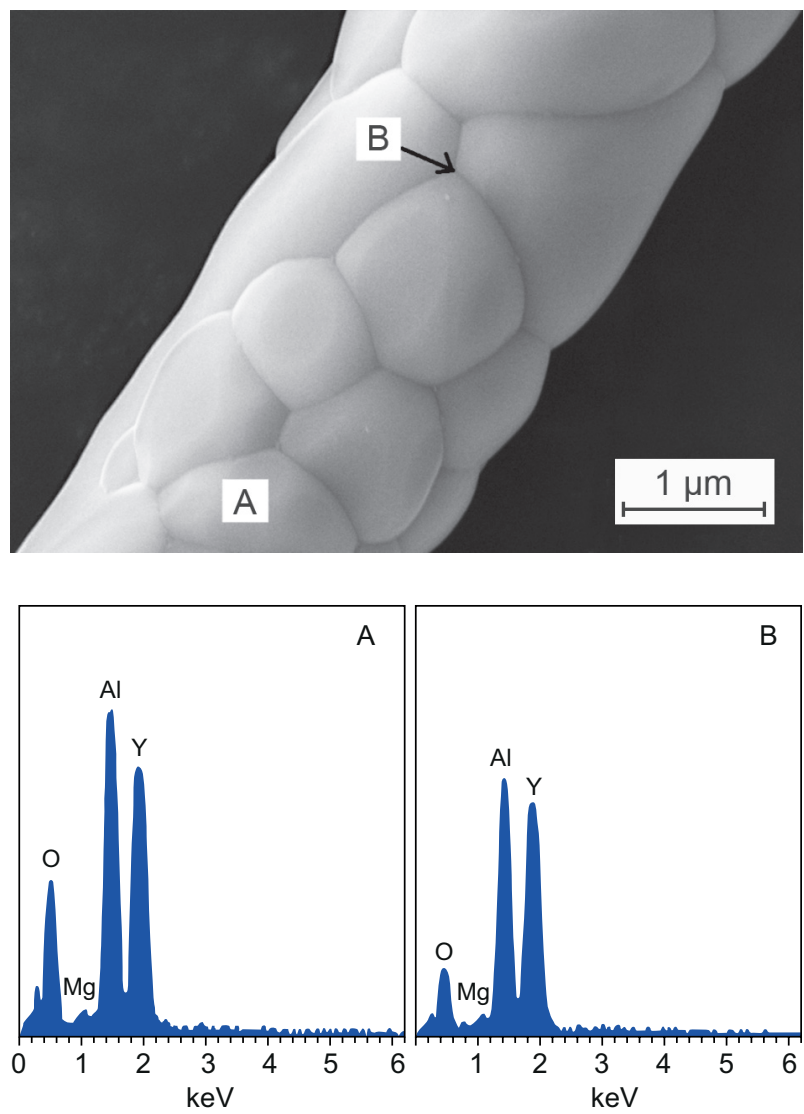

a)
The XRD patterns of YAG and the composite fibers sintered at $1600^{\circ} \mathrm{C}$ for $2 \mathrm{~h}$ are shown in Figure 3. The left-sided diffraction peak of composite fibers was wider than the peak of YAG. The inter-planar distance of (420) face became bigger by adding $\mathrm{MgO}$ because the atomic radius of $\mathrm{Mg}^{2+}(72 \mathrm{pm})$ is bigger than $\mathrm{Al}^{3+}(53.5 \mathrm{pm})$, which indicated some $\mathrm{Mg}$ dissolved in the solid solution.

SEM micrographs and EDS images of the precursor gel fibers sintered at $1600^{\circ} \mathrm{C}$ for $2 \mathrm{~h}$ and $8 \mathrm{~h}$ are shown in Figure 4, respectively. The average grain sizes of the fibers are 1.3 and $1.9 \mu \mathrm{m}$ at $1600^{\circ} \mathrm{C}$ for $2 \mathrm{~h}$ and $8 \mathrm{~h}$, respectively. According to the calculation, the fibers contained 3.6 at. $\% \mathrm{Mg}$ iron when the addition amount of $\mathrm{MgO}$ was 5 wt. $\%$.

After the gel fibers were heated at $1600^{\circ} \mathrm{C}$ for $2 \mathrm{~h}$, only a little $\mathrm{Mg}$ iron was detected in the fiber surface possibly because some $\mathrm{Mg}$ iron located inside fibers, which content of $\mathrm{Mg}$ iron at $\mathrm{A}$ and $\mathrm{B}$ spot were 0.27 and 0.15 at. $\%$, respectively.

After the gel fibers were heated at $1600^{\circ} \mathrm{C}$ for $8 \mathrm{~h}$, $\mathrm{Mg}$ iron was not detected in YAG grain (C spot). During the heat treatment process, structural defect reduces and lattice stability of grain increases. As a result, the $\mathrm{Mg}$ iron maybe excluded from the YAG grain.
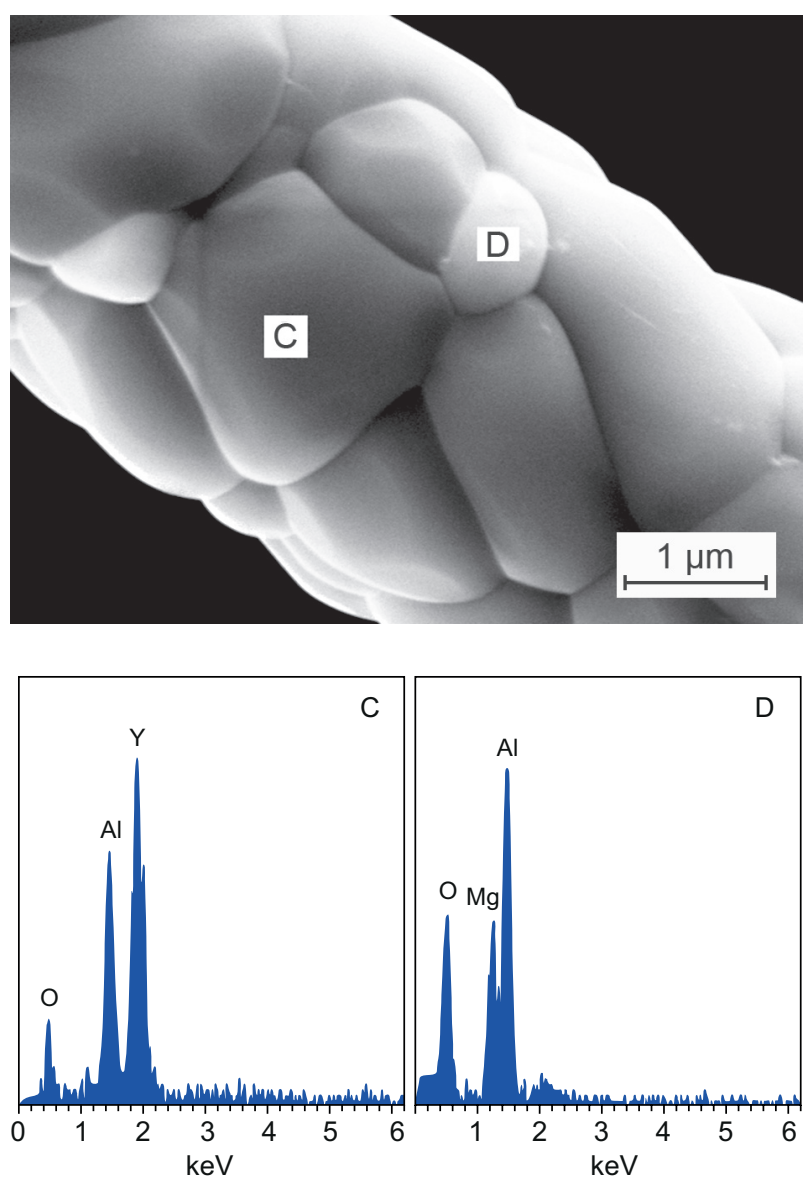

a)

Figure 4. SEM microstructures and EDS images of precursor gel fibers heated at $1600^{\circ} \mathrm{C}$ for different time. 
The grain D had different morphology from around grain, and some $\mathrm{Mg}$ and $\mathrm{Al}$ iron were detected, but $\mathrm{Y}$ iron was not detected. According to the XRD patterns and EDS images analysis result, the grain phase may be magnesia-alumina spinel $\left(\mathrm{MgAl}_{2} \mathrm{O}_{4}\right)$, which the spinel had small diameter and hindered the YAG grain growth by grain boundary pinning.

The average grain size of MAS/YAG composite fibers by sintering at $1600^{\circ} \mathrm{C}$ for $2,4,6$ and $8 \mathrm{~h}$ are shown in Figure 5. The grain size increased quickly before $6 \mathrm{~h}$, but it increased slowly after $6 \mathrm{~h}$.

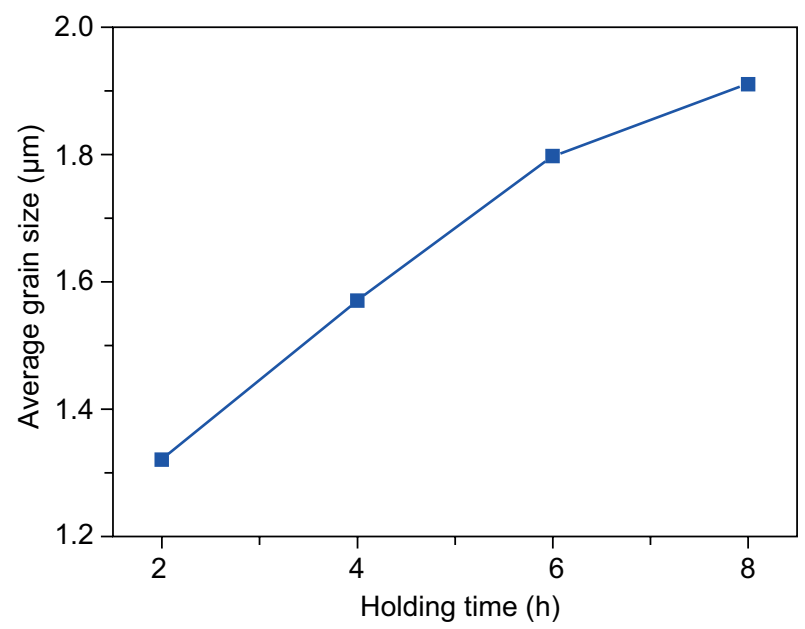

Figure 5. Average grain size of MAS/YAG composite fibers as a function of holding time at sintering temperatures of $1600^{\circ} \mathrm{C}$

The grain size increased because the surface area and surface energy of grain decreased during the heat treatment process. As a result, the lattice stability of the grain increases, the structural defects and diffusion and growth are the driving force of the grain reduction and then the grain size growth rate slowed down.

The isothermal MAS/YAG composite fibers grain growth follows the empirical law [10,16]:

$$
D^{n}-D_{0}{ }^{n}=k t
$$

where $D_{0}=$ initial grain size, $D=$ average grain size at time $t, n=$ grain growth exponent and $k=$ reaction constant. When $D_{0}$ is significantly smaller than $D, D_{0}{ }^{n}$ can be neglected relative to $D^{n}$ [22]. The Equation 9 can be given as folowing Equation 10:

$$
n \ln D=\ln k+\ln t
$$

According to Equation 10, by plotting of $\ln D$ versus $\ln t$, the grain growth exponent can be determined from the slope. Accounting to Figure 6, the grain growth exponent of the composite fibers was about 3.7.

The grain growth exponent of mullite fibers is remarkably low $(\mathrm{n}=1 / 12)$ by sintering at between 1500 and $1600^{\circ} \mathrm{C}$, and it is $\approx 1 / 3$ by sintering at above $1600{ }^{\circ} \mathrm{C}$

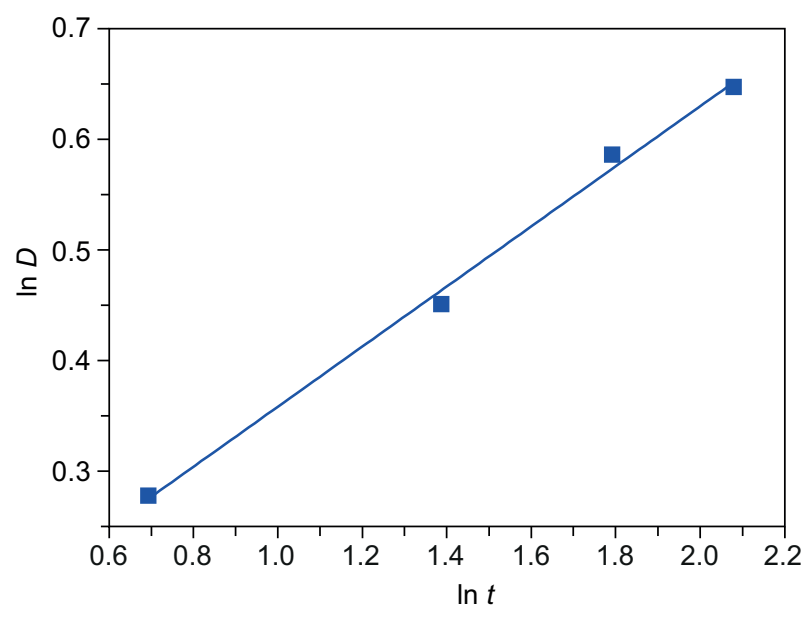

Figure 6. Grain size of MAS/YAG composite fibers vs. dwell time in logarithmic presentation.

[10]. The vacancy drag model has been used to explain the complex grain growth behaviour of mullite [10].

The grain growth exponent of pure YAG samples and the $\mathrm{SiO}_{2}$ doped samples sintered at $1745^{\circ} \mathrm{C}$ were 3 and 2, respectively [23]. A grain growth exponent of $n=2$ indicates that solid state mass transport is the dominant mechanism for coarsening [23]. In boundarycontrolled systems, grain growth exponents equal to 3 are explained by solute drag mechanisms in solid-state systems [24].

On the other hand, $\mathrm{MgO}$ can hindered YAG grain growth $[16,25]$. According to reference [26, 27], the grain growth of the composite fibers maybe attribute to $\mathrm{Mg}$ solute drag and grain boundary pinning in this work.

The grain growth exponent of YAG fibers is about 3 at $1500^{\circ} \mathrm{C}$ [24]. According to reference [16], the grain growth exponent of Cr-YAG fibers is 2.88 at $1600^{\circ} \mathrm{C}$. But the grain growth exponent of the composite fibers is higher than mullite and Cr-YAG fibers, respectively, to hider the YAG grain grow, further research continues to define these dependencies.

\section{CONCLUSION}

The spinning MAS/YAG precursor sol was obtained by sol-gel method. The length of gel fiber was remarkably dependent on the PVP addition amount. The maximum length of gel fibers was $80 \mathrm{~cm}$ when the addition amount of PVP was $28 \mathrm{wt}$ \%. The sol has optimal spinnability with 18.5 wt. $\%$ solid content, which sol viscosity was $429 \mathrm{mPa} \cdot \mathrm{s}$ at $60 \mathrm{r} \cdot \mathrm{min}^{-1}$ in shear rate. The main phases were $\mathrm{Y}_{3} \mathrm{Al}_{5} \mathrm{O}_{12}$ and $\mathrm{MgAl}_{2} \mathrm{O}_{4}$ after the fibers were sintered at $1400^{\circ} \mathrm{C}$ for $2 \mathrm{~h}$. After the gel fibers were heated at $1600^{\circ} \mathrm{C}$ for $2 \mathrm{~h}, \mathrm{Mg}$ iron was detected in YAG grain. After the gel fibers were heated at $1600^{\circ} \mathrm{C}$ for $8 \mathrm{~h}, \mathrm{Mg}$ iron was not detected in YAG grain. The grain growth exponent of the composited fibers was about 3.7. 
Ma X., Lv Z., Tan H., Nan J., Wang C.

Acknowledgments

This work was supported by the Research Fund of the National Science Foundation of China (51641106) and the Education Department Foundation of Shaanxi in China (Grant No. 16JF008)

\section{REFERENCES}

1. Li C., Zhang Y., Gong H., Zhang J., Nie L. (2009): Preparation, microstructure and properties of yttrium aluminum garnet fibers prepared by sol-gel method. Materials Chemistry and Physics, 113(1), 31-35. doi: 10.1016/j.matchemphys.2008.07.025

2. Wang R., Liu J., Ji W., Wang Y., Fu Z., Wang H. et al. (2017): Effects of ball-milling on fabrication of YAG ceramics by a phase transformation assisted spark plasma sintering. Journal of Alloys and Compounds, 701, 279-287. doi: 10.1016/j. jallcom.2017.01.128

3. Pullar R. C., Taylor M. D., Bhattacharya A. K. (2006): Effect of sodium on the creep resistance of yttrium aluminium garnet (YAG) fibres. Journal of the European Ceramic Society, 26(9), 1577-1583. doi: 10.1016/j.jeurceramsoc.2005.03.254

4. Pullar R. C., Taylor M. D., Bhattacharya A. K. (1999): The sintering behaviour, mechanical properties and creep resistance of aligned polycrystalline yttrium aluminium garnet (YAG) fibres, produced from an aqueous sol-gel precursor Journal of the European Ceramic Society, 19(9), 1747-1758. doi: 10.1016/S0955-2219(98)00283-0

5. Akram M. Y., Ferraris M., Casalegno V., Salvo M., Puchas G., Knohl S., Krenkel W. (2018): Joining and testing of alumina fibre reinforced YAG-ZrO2 matrix composites. Journal of the European Ceramic Society, 38(4), 1802-1811. doi: 10.1016/j. jeurceramsoc.2017.11.026

6. Towata A., Hwang H. J., Yasuoka M., Sando M., Niihara K. (2001): Preparation of polycrystalline YAG/alumina composite fibers and YAG fiber by sol-gel method. Composites Part A: Applied Science and Manufacturing, 32(8), 1127-1131. doi: 10.1016/S1359-835X(01)00014-8

7. Wang H., Li R., Zhou M., Cedelle J., Huang Z., Wang Q. (2017): Grain boundary sliding mechanism in plastic deformation of nano-grained YAG transparent ceramics: Generalized selfconsistent model and nanoindentation experimental validation. Journal of the European Ceramic Society, 37(7), 2705-2715. doi: 10.1016/j.jeurceramsoc.2017.02.010

8. Chandradass J., Balasubramanian M. (2006): Effect of magnesium oxide on sol-gel spun alumina and alumina-zirconia fibres. Journal of the European Ceramic Society, 26(13), 2611-2617. doi: 10.1016/j.jeurceramsoc.2005.06.045

9. Shamim M., Sinhamahapatra S., Hossain J., Lahiri S., Dana K. (2018): Kinetic analysis of magnesium aluminate spinel formation: Effect of $\mathrm{MgO}: \mathrm{Al}_{2} \mathrm{O}_{3}$ ratio and titania dopant Ceramics International, 44(2), 1868-1874. doi: 10.1016/j. ceramint.2017.10.124

10. Schmücker M., Schneider H., Mauer T., Clauß B. (2005). Temperature-dependent evolution of grain growth in mullite fibres. Journal of the European Ceramic Society, 25(14), 3249-3256. doi: 10.1016/j.jeurceramsoc.2004.08.020

11. Tan H., Ding Y., Yang J. (2010): Mullite fibers prepared from an inorganic sol-gel precursor. Journal of Sol-Gel Science and Technology, 53(2), 378-383. doi: 10.1007/s10971-009-2106-z

12. Tan H., Ma X., Lu J., Li K. (2012): Preparation of yttrium aluminum garnet fibers by the sol-gel method. CeramicsSilikáty, 56(3), 187-190.
13. Tan H., Ma X., Lu J., Li K. (2014): Effect of zirconia on crystallization of yttrium aluminum garnet precursor gel fibers. Ceramics-Silikáty, 58(2), 118-122

14. Guo L., Feng W., Liu X., Lin C., Li B., Qiang Y. (2015): Sol-gel synthesis of antibacterial hybrid coatings on titanium. Materials Letters, 160, 448-451. doi: 10.1016/j. matlet.2015.08.027

15. Feng W., Guo L., Liu X., Lin C., Li B., Qiang Y. (2015): Solgel synthesis of TiO2-modified nanocomposite coatings on titanium. Journal of Sol-Gel Science and Technology, 76(3), 715-719. doi: 10.1007/s10971-015-3868-0

16. Ma X., Lv Z., Tan H., Nan J., Wang C., Wang X. (2017): Preparation and grain-growth of chromia-yttrium aluminum garnet composites fibers by sol-gel method. Journal of SolGel Science and Technology, 83(2), 275-280. doi: 10.1007/ s10971-017-4410-3

17. Shojaie-Bahaabad M., Taheri-Nassaj E., Naghizadeh R. (2008): An alumina-YAG nanostructured fiber prepared from an aqueous sol-gel precursor: preparation, rheological behavior and spinnability. Ceramics International, 34(8), 1893-1902. doi: 10.1016/j.ceramint.2007.07.032

18. Zhang Y., Li Q., Li H., Cheng Y., Zhang J., Cao X. (2008): Sintering-resistant hollow fibers of LaMgA111O19 prepared by electrospinning. Journal of Crystal Growth, 310(16), 38843889. doi: $10.1016 /$ j.jcrysgro.2008.05.054

19. Zhou T., Zhang L., Wei S., Wang L., Yang H., Fu Z. et al. (2018): $\mathrm{MgO}$ assisted densification of highly transparent YAG ceramics and their microstructural evolution. Journal of the European Ceramic Society, 38(2), 687-693. doi: 10.1016/j. jeurceramsoc.2017.09.017

20. Jiang L., Zhang X., Tang H., Zhu S., Li Q., Zhang W. et al. (2018): $\mathrm{A} \mathrm{Mg}^{2+}-\mathrm{Ge}^{4+}$ substituting strategy for optimizing color rendering index and luminescence of YAG: $\mathrm{Ce}^{3+}$ phosphors for white LEDs. Materials Research Bulletin, 98, 180-186. doi: 10.1016/j.materresbull.2017.10.019

21. Jiang S., Lu T., Chen J. (2013): Ab initio study the effects of $\mathrm{Si}$ and $\mathrm{Mg}$ dopants on point defects and Y diffusion in YAG. Computational Materials Science, 69, 261-266. doi: 10.1016/j. commatsci.2012.11.045

22. Zhang T. S., Ma J., Kong L. B., Zeng Z. Q., Hing P., Kilner J. A. (2003): Final-stage sintering behavior of $\mathrm{Fe}$-doped $\mathrm{CeO}_{2}$. Materials Science and Engineering: B, 103(2), 177-183. doi: 10.1016/S0921-5107(03)00198-3

23. Kochawattana S., StevensonA., Lee S. H., RamirezM., Gopalan V., Dumm J. et al. (2008): Sintering and grain growth in $\mathrm{SiO}_{2}$ doped Nd: YAG. Journal of the European Ceramic Society, 28(7), 1527-1534. doi: 10.1016/j.jeurceramsoc.2007.12.006

24. Tan H., Ma X., Wang C., Li K. (2013): Kinetics of graingrowth of yttrium aluminum garnet fibers prepared by sol-gel method. Ceramics-Silikáty, 57(4), 285-289.

25. Zhou T., Zhang L., Li Z., Wei S., Wu J., Wang L. et al. (2017): Toward vacuum sintering of YAG transparent ceramic using divalent dopant as sintering aids: investigation of microstructural evolution and optical property. Ceramics International, 43(3), 3140-3146. doi: 10.1016/j. ceramint.2016.11.131

26. Boulesteix R., Maitre A., Baumard J. F., Rabinovitch Y., Sallé C., Weber S., Kilo M. (2009): The effect of silica doping on neodymium diffusion in yttrium aluminum garnet ceramics: implications for sintering mechanisms. Journal of the European Ceramic Society, 29(12), 2517-2526. doi: 10.1016/j.jeurceramsoc.2009.03.003

27. Chaim R., Marder-Jaeckel R., Shen J. Z. (2006): Transparent YAG ceramics by surface softening of nanoparticles in spark plasma sintering. Materials Science and Engineering: A, 429(1-2), 74-78. doi: 10.1016/j.msea.2006.04.072 